\title{
João Vêncio: performances de um eu amoroso que se transfigura em outros eus
}

\author{
João Véncio: performances by a loving self who is transformed into other selves
}

\author{
VINÍCIUS LOURENCO LINHARES ${ }^{1}$ \\ MARIA NAZARETH SOARES FONSECA ${ }^{1}$ \\ Pontifícia Universidade Católica de Minas Gerais. Belo Horizonte, MG, Brasil.
}

at

\begin{abstract}
Resumo: Neste artigo apresentamos uma análise de como as interações estabelecidas pelos sujeitos textuais do/no romance João Véncio: os seus amores, de Luandino Vieira, permitem que sejam flagradas emergências de subjetividades do eu/narrador, entendido como figura performática que, através de mascaramentos, transfigura-se em outros "eus" nas relações estabelecidas com seus vários amores. Para tanto, foi realizada uma breve reflexão teórica acerca da figura do narrador (BOOTH, 1980; MOREIRA, 2005) em diálogo com alguns pontos da teoria da enunciação, focalizando a subjetividade que emerge do processo de interação verbal previsto pela enunciação (BENVENISTE, 2006; BAKHTIN, 1988). Desse modo, a linha argumentativa do artigo busca uma associação entre movimentos de narratividade e o processo enunciativo do romance em análise, evidenciando como a enunciação prevê, em sua realização, a construção do narrador, entendido como sujeito textual que se desdobra na cadeia enunciativa do romance.
\end{abstract}

Palavras-chave: Amores; Enunciação; Narrador; Subjetividades.

\begin{abstract}
In this paper, we analyze how the interactions established by textual subjects from/ in the novel João Véncio: os seus amores, by Luandino Vieira, allow us to perceive emergences of narrator's subjectivities, that is understood as a performative figure that through its masking, transforms itself into other "selves" by its relationships with its multiple loves. Therefore we have done a brief theoretical reflection about narrator's figure (BOOTH, 1980; MOREIRA, 2005 ) in dialogue with some points of the theory of enunciation, focusing on the subjectivity that emerges from verbal interaction process presupposed by enunciation (BENVENISTE, 2006; BAKHTIN, 1988). Thus, this paper seeks an association between narrative movements and the enunciation process of the novel in focus in order to evidence how enunciation presupposes, in its achievement the construction of the narrator, that is understood as a textual subject that is unfoldden in the enunciation chain of the novel.
\end{abstract}

Keywords: Loves; Enunciation; Narrator; Subjectivities.

\section{Considerações iniciais}

A leitura de João Vêncio: os seus amores, do escritor angolano ${ }^{1}$ Luandino Vieira, suscita no percurso de leitura vários aspectos relativamente à sua construção literária justamente por sua riqueza composicional: pode-se ler o romance de Luandino a partir de múltiplas perspectivas, abordando, por exemplo, as vozes narrativas que atravessam o romance, a hibridação e simulação como estratégias do narrador, figura performática enquanto

1 Luandino nasceu em Portugal, mas passou a juventude em Luanda, sujeito amoroso e muito engenhoso que aciona o "muadié" 2 como interlocutor a ser conquistado. Pode-se, ainda, realizar uma leitura que aborde as performances do narrador na construção de sua(s) identidade(s) e também as performances do narrador na construção de imagens de si para o outro. É claro que outras abordagens podem ser adotadas considerando, como já acentuado, a riqueza do romance e, além disso, uma abordagem não necessariamente precisa ser feita apartada da outra.

\footnotetext{
2 Em língua Quimbunda, significa “senhor” e, no romance, constitui uma estratégia de interlocução à semelhança do que se observa em "Grande sertão: veredas", em que Riobaldo dirige sua narrativa a um interlocutor virtual e textualmente marcado.
} 
Por causa da riqueza que a narrativa desse sujeito amoroso apresenta, neste artigo, vamos nos deter sobre a seguinte indagação: como as interações estabelecidas pelos sujeitos textuais do/no romance permitem que sejam flagradas emergências de subjetividades do eu/narrador? Este entendido como figura performática que, através de mascaramentos, transfigura-se em outros "eus" nas relações estabelecidas com seus vários amores. Delimitada, portanto, a problemática sobre a qual nos debruçaremos, passemos agora à fundamentação teórica sobre a qual se assenta a leitura aqui proposta com vistas a recobrir a indagação colocada anteriormente, sem a pretensão de excluir, obviamente, outras leituras do romance.

A problemática eleita como fio condutor para a leitura aqui proposta suscita discussões relativamente à questão da subjetividade; um conceito caro às ciências humanas, de modo geral, ao se estudar o sujeito. Não é sem razão que as inúmeras áreas do conhecimento humano se debruçam em estudos relacionados a esse conceito, à semelhança da Sociologia, Filosofia e Psicanálise, por exemplo. Citemse, ainda, a própria Linguística e a Teoria da Literatura, ambas ramificadas em diversas frentes de pesquisa, mas que parecem convergir na busca de esforços que reflitam sobre questões tais como: que aspectos (e de que ordem os são) estão envolvidos na constituição do sujeito? E mais: como a linguagem permite ao humano, através dela e por ela, situar-se frente ao outro, ao mundo e a si mesmo, assumindo-se como sujeito?

Não é nossa pretensão desenvolver aqui tais questões, visto que os limites e o objetivo do trabalho seriam extrapolados. Acontece que discussões envolvendo linguagem e subjetividade sempre estão bordejadas por tais questões e fechar os olhos a essas discussões é banalizar o debate, correndo o risco de se construir um trabalho bastante frágil e pouco preocupado com as necessárias reflexões demandadas por essas indagações. Por isso mesmo, dada a amplitude da temática e pressionados pelas contingências de um artigo, circunscreveremos a discussão sobre emergência e constituição da subjetividade na perspectiva da interação verbal, recorrendo a alguns aspectos da teoria da enunciação em Benveniste e em Bakhtin.

Anunciada, portanto, a perspectiva da interação verbal, a lente com a qual lançaremos nosso olhar para o romance se respalda na enunciação, compreendida como um processo que prevê sujeitos sócio-historicamente situados e, em termos textuais, ocorre cada vez que um "eu" se enuncia, no tempo presente, convocando para o uso que faz da palavra um parceiro comunicativo - um "tu" - em um processo que prevê múltiplos desdobramentos desses sujeitos, além de uma relação intercambiável na qual, a cada instância de enunciação, o par "eu/tu" se propõe alternadamente como enunciadores e enunciatários. Sobre essa questão, façamos uma breve retomada de alguns importantes pontos que fundamentam a teoria da enunciação, trazendo para o nosso texto os dois autores anunciados anteriormente.

Como se sabe, os estudos bakhtinianos, recobrindo os mais diversos campos do saber tais como artes, cultura, literatura e também linguagem, inauguraram um novo paradigma no que se refere aos estudos desta. Nos capítulos "Língua, fala e enunciação" e "A interação verbal", ambos no livro Marxismo e filosofia da linguagem, o autor questiona duas correntes do pensamento linguístico à época de seus estudos, a saber, o objetivismo abstrato e o subjetivismo individualista. A primeira corrente considera a linguagem, do ponto de vista linguístico, como sistema detentor de uma lógica interna fixa, imanente e por isso mesmo "o sistema linguístico constitui um fato objetivo externo à consciência individual e independente desta" (BAKHTIN, 2006, p.91). A segunda corrente se orienta pela teoria da expressão e "supõe inevitavelmente um certo dualismo entre o que é interior e o que é exterior, com primazia explícita do conteúdo interior, já que todo ato de objetivação (expressão) procede do interior para o exterior" (BAKHTIN, 2004, p. 111).

Dois problemas decorrem daí: o primeiro diz respeito à rigidez de um sistema linguístico que desconsidera $\mathrm{o}$ aspecto vivo da língua, mobilizada pelo sujeito sempre em situações reais e concretas de comunicação e passíveis de interferências dos falantes. Os estudos de mudança e variação linguística demonstram bem esse aspecto. $\mathrm{O}$ segundo, o que aqui nos interessa mais de perto, é considerar a linguagem como manifestação da "interioridade" do sujeito, uma concepção essencialista de sujeito (bastantemente cultivada pelo Romantismo), que não se ocupa de discussões relativas às contingências sociais, espaciais e temporais às quais o sujeito sempre se encontra submetido. Contrapondo-se a essas concepções, Bakhtin (2009) argumenta que

[...] toda palavra comporta duas faces. Ela é determinada tanto pelo fato de que procede de alguém, como pelo fato de que se dirige para alguém. Ela constitui justamente o produto da interação do locutor e do ouvinte. Toda palavra serve de expressão a um em relação ao outro. Através da palavra, defino-me em relação ao outro, isto é, em última análise, em relação à coletividade. A palavra é uma espécie de ponte lançada entre mim e os outros. Se ela se apóia sobre mim numa extremidade, na outra apoia-se sobre o meu interlocutor. A palavra é o território comum do locutor e do interlocutor (BAKHTIN, 2009, p. 117).

Se a palavra é o território comum entre o "eu" e o "outro", assemelhando-se a uma ponte cujos alicerces são, por isso mesmo, os interlocutores, no desbravamento desse território e no trânsito por essa ponte, existem também lacunas que sulcam esse território comum, 
sacolejam a ponte em função das imagens que cada locutor faz de si e do outro no momento das interações verbais. Ademais, a dupla face da palavra evidencia relações de alteridade, de trocas - (in)tensas - entre o "eu" e o "outro" na constituição de subjetividades.

$\mathrm{Na}$ mesma direção de Bakhtin, embora tratando de problemáticas ligadas à linguística, encontram-se os estudos do linguista francês Emile Benveniste responsáveis por romper com o paradigma da linguística estruturalista, traduzido na clássica dicotomia langue/ parole (FLORES; TEIXEIRA, 2005, p.29). Tributário dos estudos de Saussure, de caráter fundamentalmente estruturalista, Benveniste avança ao propor que se trate o sujeito e a língua (entendida como estrutura) de forma articulada. Portanto, há um avanço no sentido de romper a dicotomia langue/parole e esse avanço se dá com a teoria da enunciação proposta pelo linguista francês.

Seguindo esse fio, Benveniste (1989) defende a tese de que "a enunciação é este colocar em funcionamento a língua por um ato individual de utilização." (BENVENISTE, 1989, p. 82). E mais, linguisticamente, o conjunto de categorias que cria o domínio da enunciação é a instância do EU-AQUI-AGORA. Enunciar-se, portanto, é apropriar-se de índices específicos da língua, assumindo a posição de locutor, que, linguisticamente, ocorre pela assunção do pronome de primeira pessoa "eu". Tão logo o locutor se aproprie dessa posição enunciativa, necessariamente ele postula seu alocutário que, por sua vez, assume a posição enunciativa representada pelo pronome de segunda pessoa "tu". Essa relação estabelecida entre o par "eu-tu" é cambiável e interdependente. Isso quer dizer que só é possível assumir-se como "eu" por contraste, frente a um parceiro instaurado linguisticamente pela assunção do pronome de segunda pessoa "tu". Além disso, a cambialidade estabelecida entre o par "eu-tu" é condição sine qua non para que tanto o locutor quanto alocutário possam se identificar no curso da interação. As formas que representam o par "eu-tu" são formas linguísticas que só assumem sentido no seio da enunciação, pois são formas que não remetem a nada exterior ao plano enunciativo. São signos "vazios" de referência com relação à "realidade" que só se tornam plenos, preenchidos, quando assumidos pelos locutores no exercício da fala. (Cf. BENVENISTE, 1989 , p. 84). Cada vez que um "eu" se enuncia, engendrase uma nova instância enunciativa, que se define por um ato de dizer cada vez único e pelo qual ocorre uma atualização da língua em fala pelo locutor.

Ainda em relação ao par "eu-tu", Benveniste (1995) afirma que a categoria de pessoa é própria apenas a esses pronomes não se estendendo ao pronome de terceira pessoa, "ele". Para entender a categoria de pessoa segundo Benveniste (1995), é preciso recuperar o conceito de subjetividade proposto pelo autor, a saber, "a capacidade do locutor para se propor como "sujeito" (BENVENISTE, 1995, p. 286). O locutor, pois, toma a palavra e se constitui como enunciador e, nessa constituição, já se delineia uma identidade, que confere ao falante o lugar de sujeito. Isso ocorre justamente porque "é identificando-se como pessoa única pronunciando eu que cada um dos locutores se propõe alternadamente como 'sujeito"' (BENVENISTE, 1995, p.280, grifos acrescentados). A categoria sujeito, portanto, relaciona-se à tomada de consciência de si mesmo adquirida pelo locutor frente ao seu parceiro de interlocução "tu”, dado que só é possível enunciar-se "eu" frente a um outro na interação verbal, emergindo, daí, as (inter)subjetividades.

Semelhantemente à concepção de linguagem proposta por Benveniste, Bakhtin a concebe do ponto de vista intersubjetivo, ao afirmá-la como uma atividade regida pelo princípio da réplica ativa (Cf. BAKHTIN, 2006, p. 100), em que a palavra do locutor está sempre em função da pessoa de seu interlocutor. A linguagem, nessa linha de pensamento, é também um conjunto de práticas socioculturais, concretizadas em diferentes gêneros do discurso sempre atravessados por diferentes vozes sociais. Em síntese, é esse reconhecimento do "eu" diante do "outro" (marcado pelo contraste e pela tensão) que permite a Bakhtin postular o dialogismo como um princípio constitutivo da linguagem.

Esse movimento de interação estabelecido pelo par "eu/tu" põe Benveniste e Bakhtin em estreito diálogo ao defenderem a concepção de linguagem fundada na intersubjetividade e no dialogismo (Cf. BENVENISTE, 1996; BAKHTIN, 1995). No texto literário, palco de encenações várias por excelência, essa tese se confirma, dada a porosidade da produção literária aberta a uma cadeia enunciativa ininterrupta que tensiona os sujeitos textuais - "eu" e o "outro" em seus desdobramentos. Abaixo, um esquema que ilustra a teoria da enunciação até aqui, brevemente, exposta:

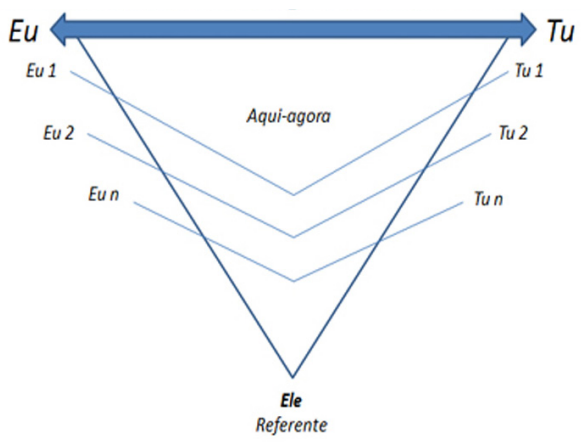

Figura 1. Aparelho formal da enunciação: desdobramentos da cadeia enunciativa

Fonte: Elaborado pelo autor a partir do esquema sobre a enunciação criado pelo professor Dr. Milton do Nascimento, da graduação e pós-graduação em Letras da Puc-Minas, em disciplinas ministradas na graduação e pós-graduação. 
Como se pode notar pela representação acima proposta na ilustração, o que se observa, além das categorias linguísticas que compõem a enunciação, é o seu caráter múltiplo, aberto a inúmeros desdobramentos responsáveis pela instauração das diversas encenações que engendram os textos, de modo geral. Cada cena, por sua vez, pode estar ligada à outra, retomando-a, reconstruindo-a, retecendo-a, sempre no tempo-espaço presente próprio da enunciação de modo que se possam realizar prospecções e/ou retrospecções. Nessa cadeia que contempla várias encenações, incluímos, aí, o narrador: um "eu" que aciona múltiplas máscaras para dizer de si e do outro, à semelhança do que bem o faz o personagemnarrador João Vêncio que não apenas assume essas várias máscaras, como também, ao tomar consciência de si frente ao outro, faz emergir suas subjetividades como sujeito amoroso, incompleto, que tenta, na busca pelo outro, possibilidades de completude.

Indo ao encontro dos pressupostos teóricos acima brevemente expostos, passaremos, agora, a um breve excurso com vistas a recobrir a categoria de narrador, haja vista ser o narrador a posição enunciativa acionada pelo romance em sua construção que encena e enuncia vários amores. Feito isso, volveremos nossos esforços no sentido de dar cabo ao objetivo central do trabalho já anunciado, mas aqui retomado, qual seja: como o eu/narrador, do romance João Vêncio: os seus amores, através de seus mascaramentos e performances narrativas, transfigura-se em outros "eus" nas relações estabelecidas com seus vários amores, emergindo, daí, possibilidades de subjetividade?

Das categorias existentes na teoria literária, talvez uma das mais complexas de ser estudada seja a de narrador. Talvez porque defini-lo não seja suficiente para perceber seus múltiplos movimentos no corpo da narrativa. Será que as classificações de narrador propostas pelos críticos - narrador de primeira pessoa, terceira pessoa, onisciente, onisciente com limites, objetivo, borboleteante e apagado (Cf. BOOTH, 1980, p.180), entre outras, conseguem recobrir toda a complexidade dessa categoria?

Booth afirma que as classificações propostas pelos críticos estão "sempre atrás, a coxear, fazendo constante referência às várias práticas que, por si sós, corrigem a tentação de generalizar demais." (BOOTH, 1980, p. 181). Assim, a simples classificação do narrador em uma obra empobrece a leitura do texto literário em toda a complexidade de sua encenação. No lugar da simples classificação, uma abordagem sobre o narrador que se oriente pelo modo como a instância narrativa é construída mostra-se mais profícua em termos de análise dessa categoria. Afinal, se o narrador é a instância que conta alguma coisa, o modo como isso é contado é de vital importância para que se possa ler o texto em sua encenação, considerando, por isso mesmo, reiteramos, o seu processo enunciativo.

O narrador pode ser comparado a uma câmera: assumindo a instância enunciativa de um "eu" (ainda que a classificação seja a de 3 a pessoa), esse "eu"/câmera, à semelhança do cinema, ora se aproxima, ora se afasta, narra/filma o que conta a partir de múltiplas posições/ perspectivas: às vezes se envolve tanto com determinada personagem, que sua voz parece misturar-se à voz dela (o contrário também é possível), fazendo ressoar, por exemplo, vozes silenciadas, em função de circunstâncias sociais, culturais, psicológicas, entre outras.

Esse narrador, sendo uma câmera, ocupa diferentes posições no cenário que apresenta para o leitor, à primeira vista, de modo imparcial. Mas o simples gesto de apresentação é atravessado pela subjetividade desse narrador que é (des)construído por um autor que se apresenta como gesto ${ }^{3}$ no corpo da narrativa e, conforme aponta Booth (1980), "de certo modo, todas as falas, todos os gestos narram" (BOOTH, 1980, p.168). A respeito desse gesto do narrador, Moreira (2005), de maneira bastante elucidativa diz que:

O GESTUS REALIZADO PELO narrador se manifesta desde a forma como se estrutura a enunciação. A fabulação se produz a partir de um movimento contínuo do narrador através de modalidades literárias que se alternam no espaço enunciativo. Em seu movimento, ora o narrador nos conta a história através de uma construção predominantemente narrativa, na qual se destaca a presença de um herói ou heroína, distanciando-se ele dos fatos que narra; ora assume uma postura lírica abertamente manifesta por um $e u$ que, no entanto, não permite a interrupção do desenrolar progressivo dos fatos; ora, ainda, dirigi-se diretamente ao leitor, inserindo-o no texto narrado. (MOREIRA, 2005, p. 156).

A realização de um gestus cria movimentos que a partir da instância enunciativa de um "eu", o narrador, convoca o leitor para que compactue de seu projeto narrativo. Não é sem razão que João Vêncio, em vários momentos de sua narrativa, liricamente, convida o leitor a um pacto de interlocução ao enunciar: "Dou o fio, o camarada companheiro dá a missanga - adiantamos fazer nosso colar de cores amigadas" (p. 13); ou ainda, "eu dou o cão - vamos na mata" (p. 28). Esse convite, que na materialidade da narrativa é dirigido a um interlocutor linguisticamente marcado - o muadié - estende-se, por

\footnotetext{
O autor como gesto é uma categoria proposta por Giorgio Agamben (2007) para dizer que o autor está presente no texto como fruto de estratégias textuais. Agamben assim fala dessa categoria: "Se chamarmos de gesto o que continua inexpresso em cada ato de expressão, poderíamos afirmar então que, exatamente como o infame, o autor está presente no texto apenas em gesto, que possibilita a expressão na mesma medida em que nela instala um vazio central.” (p.59, grifos acrescentados).
} 
sua vez, ao leitor do romance, que pode ocupar a posição desse muadié cuja interlocução é sugerida pelo discurso de João Vêncio: "Muadié ri, uelela minha sede de belezices” (p. 81).

Para fazer coro com essa rede conceitual que discute a categoria narrador, não se pode deixar de trazer como interlocutor deste texto as considerações de Walter Benjamin (1987) sobre o narrador, haja vista a guinada proposta pelo autor ao tratar o modo como essa figura passa a ser construída na modernidade. Assevera Benjamin (1987) que a grande guinada entre a figura do narrador épico para o narrador da modernidade, aquele que agora fala nos romances como forma de manifestação da/do cultura/mundo burguês que ascende ao poder após a Revolução Francesa, reside no fato de que o narrador moderno não mais comunica suas certezas, seu estoicismo e suas experiências de grandes viagens. Em um mundo eminentemente fraturado, sem a centralidade da figura divina, as dúvidas e angústias humanas vêm à tona sem o amparo dos deuses. Não há mais espaço para o regresso heroico de Odisseu que tudo suporta, ajudado e impedido pelos deuses, cujo destino, anunciado por Zeus, é regressar a Ítaca para os braços de Penélope que carde e (des)fia seu manto à espera do amado.

Ora, o narrador moderno passa a comunicar exatamente as suas incertezas, dúvidas, angústias, pedindo conselhos. Há, pois, um movimento que abala o estoicismo do herói clássico que agora se encontra "jogado" no mundo com o diferencial de que, contrapondo-se a Odisseu, esse herói moderno sabe-se abandonado pelas deidades de outrora. Em contraponto aos novos moldes narrativos, Benjamin (1987) assevera que a narrativa épica busca o bom conselho:

Ela tem sempre em si, às vezes de forma latente, uma dimensão utilitária. Essa utilidade pode consistir seja num ensinamento moral, seja numa sugestão prática, seja num provérbio ou numa norma de vida - de qualquer maneira, o narrador é um homem que sabe dar conselhos (BENJAMIN, 1987, p. 200).

O narrador construído em João Vêncio: os seus amores vai exatamente na contramão dessa dimensão utilitária, que aconselha. Ao contrário, os fios outrora tramados por Penélope, na certeza do regresso do ardiloso Odisseu, acolhido pela corte de vários reinos que o saudavam querendo saber de suas aventuras, agora cardem outros mantos, semelhantes ao manto/texto com o qual João Vêncio se (in)comunica, pedindo sentença a seu interlocutor, sobre suas incertezas que abrem e fecham o romance: "Eu queria pôr para o senhoro minhas alíneas. Necessito sua água, minha sede de ignorância... Tem a quinda, tem a missanga. Veja: solta, mistura-se; não posso arrumar a beleza que eu queria." (p.13) e "Este muadié tem cada pergunta!...: missangas separadas no fio, a vida do homem?" (p. 89).

O próprio texto, em movimento metalinguístico, encena as dúvidas e o caos desse narrador que tenta alinhar seu discurso o qual, porém, apresenta-se de modo confuso, caótico, sedento da água de um seu interlocutor a quem, reiteramos, João Vêncio comunica dúvidas, angústias. Ora, essa comunicação, por sua vez, é também incomunicação, haja vista que com o mundo moderno percebeu-se que cada sujeito traz consigo uma parcela incomunicável de sua experiência, visto que a própria linguagem coloca como problemática questões tais como: é o sujeito que fala ou é ele falado pela linguagem, à sua revelia? A questão se torna ainda mais espinhosa quando se passa a compreender a linguagem como uma atividade sempre inacabada da qual fazem parte maus entendidos e sujeitos sempre em devir. Por isso também a morte desse narrador épico e, no lugar de certezas, comunica-se, também, incertezas. Tecidas essas breves considerações sobre a categoria de narrador, cabe, agora, a análise do romance no qual, assim como João Vêncio, narrador-personagem, o amor também usa máscaras: para os gregos antigos três máscaras vestiam o amor: Eros, Ágape e Philos. ${ }^{4}$ João Vêncio, celebrando uma ode ao amor, experimenta diversos amores que parecem sempre dominados por Eros.

No presente de sua enunciação, João Vêncio encontra-se detido em uma prisão por uma "tentativa premeditada de homicídio frustrado" (p. 14). Ele flagrou sua bailundina (mulher com quem vive maritalmente) traindo-o com sô Ruas - "branco-quipanzéu" (p. 16). Sô Ruas foge pela janela e João Vêncio tenta matar sua bailundina, estrangulando-a.

É na prisão que João Vêncio narra suas cinco aventuras amorosas que, no curso da narrativa, entrelaçam-se e estão diretamente ligadas à sua constituição subjetiva ao mesmo tempo em que explicam sua prisão. Os cinco amores constituem cinco histórias distintas que se interpenetram e, por isso mesmo as histórias não são lineares. Ao mesmo tempo em que João Vêncio narra uma aventura amorosa, ele já puxa outro fio que se liga à história de outros amores. E diante de cada amor, João Vêncio se metamorfoseia/transfigura-se em "eus" amorosos distintos. Aliás, as máscaras com que esse narrador se traveste encontram-se espalhadas no próprio corpo de sua narrativa: “... palavrinhas minhas: amor, namoro, amoro, namor” (p. 76). Esse jogo lexical pode ser lido como as máscaras vestidas por esse eu/narrador que se transfigura em vários à semelhança das palavras citadas por ele que conservam um mesmo radical (amor) ao qual são justapostos outros morfemas (talvez seus amores).

\footnotetext{
4 Eros representa o amor erótico, carnal, Ágape é o amor incondicional, e Philos é o amor amigo.
} 
Embora sejam narradas cinco aventuras amorosas, três, em especial, são os amores que mais marcaram a existência de João Vêncio: "Eu tinha mas é três amores que eu vou pôr primeiro para o muadié perceber inteiro. Porque de todos os outros eu não lembro a luz que esses três têm em meu coração" (p. 18, grifos acrescentados). Esses três amores, a saber, são a Màristrêla, o Mimi e a Tila e os outros dois amores são de sua bailundina e a prostituta Florinha.

Màristrêla é o amor feioso de João Vêncio. Filha de um caboverdiano, ela tinha seis irmãos e todos passavam fome devido à condição de miséria em que viviam: "O pai dela [Màristrêla] e dos seis pucos ${ }^{5}$ com fome, uma escada de filhos, miséria." (p.30). Por causa da miséria, Màristrêla, "aos dozes anos prostitutou-se." (p.30). Com ela, em sua infância, João Vêncio caçava passarinhos para cegá-los: "E eu via-lhes [olhos de Màristrêla] luzir o brilho verdiano, espetando as agulhas de croché que eu afiava. Que era nosso jogo: cegar os bichinhos para eles cantarem melhor." (p. 50) imaginando estar cegando o "doutoro", advogado que morava no musseque ${ }^{6}$ e havia trazido a menina Tila do asilo para ser sua mulher.

$\mathrm{O}$ tempo que passavam juntos na caça de passarinhos pelo musseque tornava Màristrêla e João Vêncio próximos e dessa aproximação surge o desejo dele por ela:

No meu canto de dormir, no chão de esteira - ela [ Màristrêla] comigo, a minha mão no seio e eu a furar os olhos do doutoro. Com o cheiro de pão torrado do seu embaixo de vestido. Eu vivo muito dentro de mim - as coisas vêm, voam. Só que ela não aceitou - me deu quissende [recusa] que eu guardo, dor de minha alegria (...) (VIEIRA, 1987, p. 32).

Travestido de Eros, o amor de João Vêncio encontra recusa no não de Màristrêla que fica em sua memória, sobretudo pelo olfato, ao rememorar o cheiro de pão por baixo de seu vestido. Há, ainda, uma mistura de cenas, de memórias de contato, cheiros e amores espalhados pela narrativa, o que se evidencia quando João Vêncio justapõe a cena da caçada de passarinhos entre ele e Màristrêla a outro fio da trama: a história da menina Tila, também, um de seus amores. E mais, desloca-se, e por isso transfere, o movimento de cegar os passarinhos para

\footnotetext{
5 Em Quimbundo quer dizer ratos. No romance, puco faz referência à condição de miséria da família de Màristrêla e à sua feiúra conforme nos narra João Vêncio: "É por isso eu digo a Màristrêla, verdianinha, era minha namorada de verdade. Feionga, cara de puco..." (p.29, grifos acrescentados).

6 Em Luanda, é onde mora a maioria da população pobre. A palavra musseque tem origem no kimbundo (mu seke) e significa areia vermelha. A um dado momento, musseque, passa a designar os grupos de palhotas, que se adensam no alto das barrocas e que por semelhança à SEKE (vermelho ocre) toma o nome do material (areia) sobre o qual se implantam. O seu desenvolvimento está intimamente ligado ao da cidade propriamente dita.
}

os olhos do doutoro. Olhos estes que, metaforicamente, podem ser lidos como a censura de um outro a barrar o desejo do narrador e que, por isso, precisa ser eliminado de modo que o desejo reine absoluto. Dessa tensão, desse barramento, esse narrador se faz sujeito pela censura dos olhos do doutoro e recusa de Màristrêla, encontrando na linguagem, em sua narração, possibilidades de se constituir como sujeito.

Nessa co(n)fusão de cenas, memórias e cheiros explicitadas na narrativa de João Vêncio, unem-se outras rememorações do narrador que segue contando ao muadié amores que se interpenetram e, por vezes, não se sabe com clareza a qual amor João Vêncio se refere e, por isso, reiteramos, um fio se entrelaça ao outro como bem se observa na passagem seguinte:

E ela abria os olhos e deixava eu meter-me em baixo de seu vestido comprido, encostado nas pernas quentes. Ria. O cheiro húmido e seco desses dias não sai mais de meu coração, muadié. Pirsigui-lhe toda a vida, procuro em todas as baronas que eu tive e não lhe dou mais encontro. Era o paraíso de perfumes, só dela. Depois eu deitava a cabeça no colo e ela anelava meus mulatos caracóis. Mas eu não gostava dela como ela queria - ela queria o mona, o filho (...) (VIEIRA, 1987, p. 19).

Fazendo referência ao cheiro da madrasta do qual não consegue se esquecer, João Vêncio parece "emendar" memórias a memórias, as quais, por sua vez, também o constituem sujeito. Sujeito transitivo que anuncia ao leitor perseguir cheiros que permanecem nele, o que justificaria a intensidade das memórias olfativas ao longo da narrativa. Emendando memórias, esse sujeito amoroso apresenta ao leitor alguns nós de seus amores como o que se segue:

Não é a Màristrêla - aliás: Maris Stella, latinório que eu depois conto - é a outra, a segunda ponta da estrela-de-três, que é também a primeira. A meninaórfã, de asilo. Abri minha caixa de fóisfos, ela já estava se pentear das minhas pancadas desengasgadoras. Nem que me ligou; levantou, foi para dentro. Mas eu tinha o gosto das gajadas nos meus beiços, tinha deitado fora dois ratos inchados, caçados de noite com o milongo da minha madrasta, as agulhas afiadas deixara-lhes no canto de brincadeiras com a minha namorada 'verdiana. Fui atrás dela até no quarto deles. Ela estava em combinação, mudava o vestido. E mudava a combinação. Ela estava em camiseta. E mudava a camiseta. Ela estava só com os panos negros bordados, bonitos, de rendas brancas no peito e as compridas calcinhas de refolhos-folhos, amarradas nos joelhos com fitinhas cor de rosa amarela. E deixou-me aninhar no seu cheiro, um torrume que eu continuo procurar até hoje com pomadas e folhas-d'erva, colónias e brilhantinas e nada! Ele só existe é na minha memória? (VIEIRA, 1987, p. 33, grifos acrescentados). 
No trecho, o narrador mistura amores, mistura cheiros e, também, memórias. Além disso, como se observa no primeiro grifo, a imagem da "estrela-de-três", simbolizando os amores do narrador, parece ser girada por João Vêncio sem que este consiga determinar com precisão algum grau de importância de seus amores, evidenciando para o leitor paradoxos, ideias caóticas de um narrador que se faz sujeito frente à dispersão de si mesmo e de seus amores.

Ao enunciar que "a segunda ponta da estrela-de-três, que é também a primeira" como se poderia compreender tal asserção (numa lógica binária, incoerente) senão como um movimento de interação, de um "eu" - que ao encontro do(s) outro(s) - se faz sujeito? E mais, como já acentuado antes, o excerto mostra um sujeito incompleto cuja memória olfativa traz para a cena Màristrêla e Tila, misturando-as, tornando, por isso mesmo, a segunda ponta também a primeira, o que traduziria, em palavras, os cheiros que permanecem na memória do narrador.

Tila, outro amor de João Vêncio, chegou ao musseque trazida por um homem denominado doutoro: "Eu queria deitar fora e amar só a minha menina mais-velha - eu já tinha oito anos. Mas ela pensava eu era filho dela - e eu queria furar os olhos do doutoro.” (p. 33). Mencionando o desejo de furar os olhos do doutoro, João Vêncio mistura Tila à Màristrêla como será visto mais adiante.

Enquanto João Vêncio se encanta por Tila, desejando-a, tomado por Eros, Tila - "moça fina, louçada-china" (p. 35) o via como filho e o doutoro interditava o desejo de João Vêncio por Tila: "e deixava eu segurar-lhe nas fofas mamas que tinha, suspirava. E eu queria fazê-la chorar para ter a coragem de fazer o que eu vivia com ela no meu escuro: matar o doutoro, amar com ela." (p. 20, grifos acrescentados). Insinua-se aí o trágico destino de Édipo, visto que o excerto pode sugerir, por meio de "meu escuro", uma metáfora para o desejo interditado: matar o doutoro (metáfora do pai) para ter acesso à mãe. Tentativa frustrada visto que Tila, assim como Màristrêla, recusa a proposta de João Vêncio de "sassinar" o doutoro:

$<<$ Quero-me casar contigo $>>$. $<<$ E o doutoro? $>>-$ ela mesmo ainda lhe tratava de doutoro. $<<$ Eu mato, 'sassino! >> E falei o que ia fazer: as migalhas de pão com o milongo [...] Eu até ri: estriquinina - eu gostava esta palavrinha de vidro moído. [...] Senhoro nunca lhe deram bofetão no ouvido inteiro, no silêncio de sua distracção? [...] Surra que ela me deu andei semanas a esconder de meu pai. [...] Mulher-cadela, eu gostava dela. Ela é a ponta um da estrela, a toda ela [...] saquelou o meu destino: $<<$ Pequeno assassino... $>>$. (VIEIRA, 1987, p. 34-35).

O amor por Tila é interditado e João Vêncio se metamorfoseia em um sujeito barrado. Porém, esse barramento, por sua vez, não encontrou interdição no amor de Mimi, pois João Vêncio assim diz em relação a seu amor por Tila: "ainda o meu amor continua, procuro ela [Tila] em todo o lado. Moça fina, louça-da-china deu-me o corpo do Mimi” (p. 35). De corpo em corpo, o narrador busca realização de seu desejo. Não podendo ter o encontro com o corpo de Tila, João Vêncio se deságua no corpo de Mimi.

\section{Eu e ele. Ele e eu}

João Vêncio, mais de uma vez, nos confessa horror à solidão: "o que eu tenho mais medo no mundo só, é ficar só, disso confesso" (p.36) e "o deserto humano, solidão de sozinho." (p.84). Talvez por isso se justifique essa incessante busca pelo outro - seus amores - afastando-o, assim, da solidão. Essa busca encontra na superfície da construção textual um movimento de dança: "Eu e ele. Ele e eu. Sem vergonha, nossas amorizades." (p. 71). A alternância dos pronomes encena essa dança cujo movimento parece ser o de encontro entre os parceiros que dançam: João Vêncio e Mimi, além do neologismo formado pela junção de "amor" e "amizade", evidenciando $o$ encontro entre os personagens.

Mimi é um garoto que veio com sua mãe viúva morar próximo ao musseque: "Nesse dia eu lhe acompanhei até na casa dele - no outro canto de baixo de nosso musseque, casarão fugado em meio de jardim..." (p. 37). Inicialmente João Vêncio e os outros garotos do musseque perseguem Mimi por causa de seu jeito diferenciado, filho único e mimado: "E os olhos grossos, pretos, paco-paco sempre e o cabelo loiro de cruéis caracóis - que lhe cortamos rapado no primeiro dia que ele veio." (p.36).

O discurso amoroso de João Vêncio exala lirismo ao explorar aliterações de fonemas oclusivos $/ \mathrm{p} /$ e $/ \mathrm{k} /$ responsáveis pelo ritmo com que João Vêncio desenha Mimi para seu interlocutor. Esse trabalho com a língua feito por Luandino encontra-se em todo o corpo da narrativa. Um momento memorável desse trabalho lingüístico a serviço do ritmo é um dos encontros entre João Vêncio e Mimi: "os nus e o mar" (p.54). Vamos então sentir esse ritmo da cena:

Perto da minha cara achatetada o fino nariz dele respirando. $<<$ Diz lá: mar! $>>E$ eu dizia meus ás fechados. $<<$ Não! Mar! $>>$ A boca rosa dele, a espuma das ondas nos dentes. Fazia força, pegava meus beiços arredondava: $<<$ Mar! $>>$ Até que deu encontro o búzio amarelo. Ajoelhou diante do meu corpo escurecido, encostou na orelha direita. E eu ouvi a boca dele, a palavra dele no ouvido, no peito, no meu coração. Eu disse: $<<$ Mar! $>>$ e eu só gritei: $<<$ Mar! Mar! $>>$. Ele levantou, o búzio na mão e eu com ele, abraçado: $<<$ Mar! Mar! Mar! $>>$. Até a água que borbulhou nas nossas bocas, íamos indo, unidos, no dentro do maròciano... (VIEIRA, 1987, p. 54) 
Aos ás fechados de João Vêncio, contrapunham-se os às abertos de Mimi. A diferença prosódica das personagens faz referência também aos vários moradores do musseque que abarcava pessoas de vários lugares de África e suas línguas. Ressalte-se, ainda, que Mimi é bem diferente dos outros garotos do musseque que o recepcionam rapando seus blondes caracóis. A passividade de Mimi diante dos maus tratos, logo fez com que os garotos parassem de persegui-lo e João Vêncio passou a ser seu protetor, apaixonando-se por Mimi. Esse amor, por sua vez, acompanha João Vêncio por toda sua vida, marcando-o, riscando-o e pedindo "veredicto" de seu interlocutor: "como pode-se mesmo ser amigo de mulher e amor de homem." (p. 14). Essa estratégia de interpelação acentua o caráter de performance desse eu amoroso para quem "as palavras mentem mas as pessoas falam a verdade com elas" (p.74). Esse jogo de máscaras torna a narrativa de João Vêncio extremamente sedutora e, muitas vezes, enreda o leitor que pode se perder na malha amorosa do romance que também é ardilosa, estratégica, compondo a cadeia enunciativa do/no romance.

Sobre Mimi, João Vêncio confessa ao leitor: "descobri que eu amava mais o Mimi" (p.32). Com o garoto dos "blondes caracóis" (p.36), João Vêncio experimenta Eros nos líricos mergulhos no "maròciano". Acompanhemos os amantes:

Tirámos a roupa, nadámos. Sujámos o corpo, lavámos. E sentámos, nós os nus, na cara da água, esperando nossa sereia. Veio: era a noite, princípio dela só, com xaxualho fresco. Então ele segurou minha mão, abraçou: <<Juju, tu és o meu amigo, sempre, sempe? $>>$ E eu jurei. $<<$ E nunca mais nos vamos separar, sempre? $>>$ E eu sacudi minha cabeça, eu queria chorar. Chorei mesmo, nos abraçámos, soluçava urrando, ferido e pancado pior que a mão dela, Tila, no canto do quarto. E era a lua, grande, em cima do muxixeiro, azula, azul, a gente podia-lhe ver subir no céu, ria o seu homem-monangamba. A passarinhada roussinolava. $<<$ Vamos! $>>-$ segurou minha mão. Mas eu senti que não podia voltar mais para casa antes do que eu queria, do que eu fui chamar com meu assobio em baixo do pau; eu queria ser todo, todo dele, do meu amigo. Abracei-lhe, segurei-lhe, encostei no peito dele, deitámos no chãozinho, meio do capim, beira d'água azul com música de rãs-relas e ele sorriu-se todo, era o sol. Fizemos. Eu e ele. Sem vergonha, nossas amorizades. E eu então contei-lhe tudo da menina Tila e da Màristrêla - e ele não ciumou. $<<$ Isso tudo não existe: só tu e eu! >> (VIEIRA, 1987, p. 70-71).

A dicção lírica de João Vêncio parece afastar o leitor da tentação de condenar esse sujeito amoroso que agora, novamente, se desdobra, transfigurando-se em outro sujeito amoroso. Desdobrando-se nessa condição, o discurso de João Vêncio não permite que se dê um veredicto incisivo, sem considerar a rasura desse amor na existência desse narrador amoroso que, interpelando o muadié - e também o leitor - questiona: "Quem não me conhece, como é quer me conhecer?" (p. 48-49).

Além de se comunicar por um discurso escorregadio, ardiloso e, por isso, a incisividade seria um movimento de leitura oposto à proposta autoral que se vê no/com o romance, é interessante notar que a busca de João Vêncio pelo outro é incessante. Na bela cena acima transcrita, essa busca se (ir)realiza quando se observa o pacto de "encontro" realizado através das juras de amizade para sempre, o que se desfaz, visto que Mimi já morreu no presente da enunciação instaurado pelo narrador, mas que, por outro lado, revive nas palavras narradas por João Vêncio e, por isso mesmo, por força da palavra: palavra ponte, palavra território comum entre o "eu" (João Vêncio) e o outro (Mimi) permite que João Vêncio num processo de escrita (criado, é claro, pelo autor empírico), que reconta as vivências desse narrador, singularize-se como sujeito frente a esse outro amor para o qual tece elocubrações: "eu queria ser todo, todo dele, do meu amigo" (p. 71). Tal singularização, por sua vez, parece ficar extremada na reposta de Mimi: "Isso tudo não existe: só tu e eu!” (p.71). O fundamento mesmo da subjetividade com o qual vimos trabalhado aqui se manifesta na suspensão proposta por Mimi a João Vêncio: a inexistência dos outros amores, enunciada por Mimi "só tu e eu!" - intercambiando as posições enunciativas, intersubjetivamente, faz emergir sujeitos amorosos, tomados por Eros, na declaração do narrador: "Fizemos. Eu e ele. Sem vergonha, nossas amorizades." (p. 71).

\section{A estrela de três pontas ${ }^{7}$}

Na narrativa de João Vêncio não faltam movimentos de intertextualidade que, entre outros efeitos, gera ruídos, povoando o romance de várias vozes. Dos intertextos com os quais Luandino tece o romance, o discurso religioso cristão é abertamente mostrado na voz de João Vêncio. Um desses intertextos parece ser a planta baixa do romance sobre a qual se arquiteta a "base bruta" da narrativa de João Vêncio. Chamamos de "base bruta" a camada do texto que sustém, em termos metonímicos (o todo pela parte e vice-versa), a narrativa para a construção de outras camadas que, por sua vez, retomam, replicam essa "base bruta". Seria aquilo que Candido (1996), retomando Emil Staiger, no estudo, deste autor, intitulado Die Kunst der Interpretation vai dizer sobre a hermenêutica literária: o todo se afina nas partes e as partes se afinam no todo

\footnotetext{
7 Um trabalho extremamente minucioso a respeito da metáfora da estrela na narrativa de João Vêncio foi realizado por PINHEIRO (2002). A referência completa do estudo feito pela autora encontra-se nas referências deste artigo.
} 
em se tratando da obra literária (Cf. CANDIDO, 1996, p. 18-20).

Santíssima trindade, Nossenhor me desculpe, é como eu vejo esses dias do antigamente. Padre sô Viêra é que me explicou como a estrela de três pontas é uma só. Ela era a mulher do doutoro; e a Màristrêla minha namorada que eu não queria; gostar só gostava do Mimi, de cabelo caracolado e grossos olhos negros. E nunca mais posso estar assim, todo eu em todos. Já não é a mesma coisa - só no nascente o Kuanza não é rio sujo, mentira muadié? (VIEIRA, 1987, p.23).

O excerto acima pode ser lido como a "base bruta" da narrativa nos termos expostos anteriormente. Fazendo uso do discurso religioso cristão, João Vêncio compara seus três amores - a estrela de três pontas - ao mistério da Santíssima trindade: mesmo sendo três pessoas (Pai, Filho e Espírito Santo) é apenas uma. E é justamente isso que Màristrêla, Tila e Mimi representam: são três amores, mas representam um só amor e por isso mesmo cada um atravessa o outro, atravessando, também, o próprio João Vêncio em sua constituição subjetiva e, ainda, toda a escrita do romance.

Em diálogo com a Santíssima Trindade, que é um dogma e por causa disso não se questiona, ao dizer que "a estrela de três pontas é uma só", João Vêncio, ao invés de dogmatizar seus amores, acena para seu interlocutor pedindo-lhe que não the dê veredicto a partir de uma lógica dicotômica, mas que sinta a pungência de seus amores. E por isso, também, talvez João Vêncio queira dizer ao muadié que existem outras lógicas, outras formas de agir e pensar.

Se Màristrêla, Tila e Mimi estão na "base bruta" da narrativa, Florinha e Bailundina compõem outra camada do romance. Florinha era uma prostituta que morava no musseque e tinha um filho: Ninito, que morreu depois que foi mordido por um cão. Depois de sua morte, todo dia dez, a "prostibruta" (p.76) realizava um ritual de passagem do filho a partir do qual fazia a iniciação sexual dos garotos do musseque.

No princípio não aceitava comigo, era miúdo feijão. Depois eu fui a primeira vez - era depois de ver o primeiro zoológico doutor, guinchado. Bufei, denunciei: ela estava estendida na esteira, tão amarrotada, eu tive pena, lembrei minha menina do asilo que eu queria e vi o rangotango-macaco gritando - mergulhei. E tive raiva. A florinha me segurou nos ombros, murmurava: $<<$ Cuetado! Mon' a uisu hanji ... Tão pequenino, pipito iala kué, mon'ami? $>>$ Tive as raivas: eu tinha oito anos..." (VIEIRA, 1987, p. 78).

A construção da cena de iniciação sexual do narrador opera com deslocamentos que constroem belas imagens e também atualizam a cena de relação sexual entre o doutoro e a Tila presenciada por João Vêncio. Num gesto que procura imitar o doutoro, João Vêncio, com oito anos, é barrado por Florinha para quem João Vêncio ainda não estava preparado para o ritual de iniciação sexual e isso, em termos imagéticos, é sugerido pela imagem do "miúdo feijão". Essa construção, por sua vez, é mais uma máscara com o qual esse narrador se veste para nos contar suas aventuras amorosas. Máscaras que deixam muitas lacunas na narrativa como é o caso da própria Florinha que era o centro da estrela de João Vêncio (Cf. p. 62). Talvez ela ocupe esse centro por representar a mãe que João Vêncio não teve: "A Florinha - eu falo o nome bonito dela e vejo a minha mãe, desconhecida madre." (p. 80).

Por fim, a quinta aventura amorosa de João Vêncio é a bailundina, com quem ele vive maritalmente e a quem tentou matar por encontrá-la na cama com outro homem e por isso se encontra preso. Após esse episódio, João Vêncio perdoa sua bailundina e, no presente de sua narração, ele espera a visita dela com seu almoço: "ela [a bailunda] vem hoje trazer suas lambetas [comidas] bailundas que eu lhe convido já para assentar comigo". (p. 15).

\section{Considerações finais: todo eu em todos}

\author{
"Tu deves amar a teu próximo porque tu \\ és teu próximo. É ilusão acreditar que teu \\ próximo seja outro que não tu mesmo."
}

(RADHAKRISHNAN, ex-presidente da Índia)

A epígrafe com a qual dialogamos para as considerações finais de nosso texto vai ao encontro do fundamento da subjetividade que orientou a análise proposta. Considerando a subjetividade na perspectiva da interação verbal, é possível observar, e confirmar, que o sujeito se constitui como tal sempre frente a um outro. Em termos linguísticos, o par composto pelos pronomes pessoais "eu/tu" são intercambiáveis no curso das interações e, por isso, as palavras de Radhakrishnan apontam para um modo de se perceber o sujeito inscrito, constituído a partir do olhar do outro, fazendo lembrar que a intersubjetividade fundamenta a subjetividade (cf. BENVENISTE, 2006, p. 80).

Em João Vêncio: os seus amores observa-se um narrador questionador, que planta dúvidas e incertezas em sua narrativa, pedindo a seu interlocutor (o muadié e os leitores) um pacto de comunicação. E os constantes questionamentos espalhados por sua narrativa parecem sempre querer rasgar uma lógica dicotômica, um discurso taxativo que busca sempre delimitar fronteiras: "Agora o muadié me diga ainda: ser e não ser, ao mesmo tempo, pode-se? Gostar e não gostar, dor e alegria, água e 
fogo?" (p. 31). A esses questionamentos parece não haver respostas fechadas diante de questões abertas e por isso mesmo a dúvida se instala e o sujeito emerge, assumindo múltiplos posicionamentos.

A estratégia de justapor elementos antitéticos só faz acentuar os mascaramentos desse sujeito amoroso e impossibilita que se demarquem fronteiras, visto que estas se mostram sempre borradas pelo discurso de um eu amoroso em constantes transfigurações/metamorfoses e para cuja narração pede aval de seu interlocutor. Ao propor um pacto de interlocução/leitura, esse eu amoroso dá o fio, ou melhor, os fios, e pede a seu interlocutor que dê as missangas. Narrando seus amores, João Vêncio também os revive e sua narrativa, tecida em várias camadas, não se permite a um único enquadramento, ou mesmo ao veredicto pedido por ele.

Narrando seus amores, João Vêncio movimenta-se de maneiras distintas, em tons e perspectivas também diferentes e por isso mesmo o corpo do texto assume os mais variados contornos e relevos ao mesmo tempo em que faz emergir as várias máscaras de João Vêncio, podendo tragar, também, o leitor para esse jogo performativo no qual as constituições subjetivas são múltiplas e desdobráveis: quer sejam entre João Vêncio e seus amores, entre João Vêncio e o muadié e, por que não, entre João Vêncio e os leitores? Confessando-se escravo de seus amores e com extremo medo da solidão, ele faz uma verdadeira ode ao amor, mostrando aos seus interlocutores a única maneira de se dizer/sentir "eu" e transfigurar-se nessa condição: ir ao encontro do(s) outro(s), desaguando em mar, oceano: maròciano; e consumir-se completamente na própria trama de sua narração que também, possivelmente, consumirá os leitores, constituindo possibilidades de emergências de subjetividades.

\section{Referências}

AGAMBEN, Giorgio. O autor como gesto. In: Profanações. Tradução Selvino José Assmann. São Paulo: Boitempo, 2007. p. 55-63.

BAKHTIN, Mikhail. Língua, Fala e Enunciação. In: BAKHTIN, Mikhail. Marxismo e filosofia da linguagem. Tradução Michel
Lahud e Yara F. Vieira. 13. ed. São Paulo: Hucitec, 2009. p.93-113.

A interação verbal. In: BAKHTIN, Mikhail. Marxismo e filosofia da linguagem. Tradução Michel Lahud e Yara F. Vieira. 13. ed. São Paulo: Hucitec, 2009. p. 114-132.

BAKHTIN, Mikhail. O plurilingüismo no romance. In: Questões de literatura e de estética: a teoria do romance. São Paulo: HUCITEC, 1988. p.107-133.

BENJAMIM, W. O narrador - considerações sobre a obra de Nikolai Leskov. In: Magia e técnica, arte e política. Tradução de Sergio Paulo Rouanet. São Paulo: Brasiliense, 1987. p. 197221.

BENVENISTE, Émile. A linguagem e a experiência humana. In: Problemas de linguística geral II. Tradução Eduardo Guimarães. 2. ed. Campinas, SP: Pontes Editores, 2006. p. $68-80$.

O aparelho formal da enunciação. In: Problemas de linguística geral II. Tradução Eduardo Guimarães. 2. ed. Campinas, SP: Pontes Editores, 2006. p. 81-90.

BOOTH, W. A retórica da ficção. Tradução Maria Teresa H. Guerreiro Lisboa. 1. ed. Lisboa: Arcádia, 1980. p. 167-181.

CANDIDO, Antônio. O estudo analítico do poema. São Paulo: Humanitas Publicações/FFLCH/USP, 1996.

MOREIRA, Terezinha Taborda. Contar e cantar. In: $O$ vão da voz: a metamorfose do narrador na ficção moçambicana. Belo Horizonte: Edições Horta Grande, 2005. p. 156-166.

PINHEIRO, Layss Helena Teodoro. João Vêncio: os seus amores: escritura neopicaresca e angolanidade. $110 \mathrm{f}$. Tese (Doutorado em Letras) - Faculdade de Ciências e Letras da UNESP, São Paulo, 2003.

VIEIRA, José Luandino. João Vêncio: os seus amores. Lisboa: Edições 70, 1987.

Autores:

VINÍCIUS LOURENCO LINHARES

Pontifícia Universidade Católica de Minas Gerais.

Belo Horizonte, MG, Brasil.

vinicius.linhares@ifmg.edu

MARIA NAZARETH SOARES FonSECA

Pontifícia Universidade Católica de Minas Gerais.

Belo Horizonte, MG, Brasil.

nazareth.fonseca@gmail.com

Recebido: $27 / 04 / 2017$

Aprovado: 27/04/2017 